Without any additional expense, 120 extra students could be accommodated. Instead of being empty over the summer vacation, the department would be full, but Professor Adamson points out that this would not involve the staff in any inconvenience, since they are already teaching five M.Sc. courses during the summer and are used to staggering their holidays. Some students might have to go up to university in January instead of October, but this does not seem unreasonable.

Professor Adamson admits that his system would call for considerable managerial skill on the part of the Head of Department, but this, too, is not an unreasonable thing to ask. He is also concerned about the gap which seems to be developing between the courses organized by the Council for National Academic Awards and the courses for what used to be the Dip. Tech. The former courses will presumably go into the polytechnics, while the old Dip.Tech. courses are now the responsibility of the University Grants Committee. In this respect, too, the Institute of Science and Technology at Manchester is dismayed by duplication. Its views will no doubt bring encouragement to the Committee of Vice-Chancellors and Principals and to the University Grants Committee now seeking to make better use of university facilities. Manchester will know, of course, that this is merely another example of "what Manchester does today, London does tomorrow".

\section{Robbins Misconstrued}

$\mathrm{BY}$ accepting literally the recommendations of the Robbins Committee and ignoring the philosophy behind them, the British Government is putting at risk the economic future of the country, says the Vice-Chancellor of the University of Lancaster, Mr. Charles F. Carter, in his second annual report. Not only had the Robbins figures assumed that university entrance would become more difficult, but they had also used estimates of the numbers of qualified school leavers which were soon replaced by substantially higher figures. As a result, Mr. Carter said, it had become even harder to get into university than the Robbins Committee wished.

Attempts were being made to rescue the situation by setting up polytechnics, but these were regarded by the universities as a sort of nationalized university and by the technical colleges as a way of limiting higher work to a few favoured institutions in the south of England. Mr. Carter said that there is a real danger that the British system is making at $18+$ the mistake it is trying to remedy at $11+$ by the introduction of comprehensive schools. The greatest danger of wasted talent arises with boys and girls who have studied arts or social science subjects at school, but are unable to get into universities; it is not at all clear that this is a need which the polytechnics could meet. Mr. Carter urged parents to be militant in support of children who were likely to be denied the opportunities which they deserved.

He said that, at Lancaster, only 365 applicants could be offered places from a total of 6,200. Many of those turned down were very well qualified, but he feared that they would be unable to obtain university places anywhere in the country. Mr. Carter thanked his staff for taking on 1,225 students in 1966 instead of the planned 1,150 , and promised to keep searching for ways in which the "productivity" of the university could be increased.

\section{Research in U.S. Industry}

THE continuing growth of research and development in the United States, and the continuing dominance of research on aircraft and missiles, is clear from the latest instalment of the National Science Foundation's survey (Basic Research, Applied Research, and Development in Industry, 1964, National Science Foundation 66-28, Government Printing Office, 65c.). Between them federal government and industry spent $\$ 13,400$ million in 1964, an increase of 6 per cent compared with 1963 . This further growth of research and development implies that the total expenditure on industrial research and development in the United States has increased at a rate of 13 per cent per annum compound since 1953 , although it is plain that, in the past two or three years, the pace of growth has slackened. The contribution of the federal government to industrial research and development remains at just under 60 per cent of the whole - a proportion which has remained fairly constant (at between 56 and 59 per cent) since 1957 and the beginning of space and missile programmes now responsible for a good deal of government expenditure in industry. In 1953, the proportion of federal money in industrial research was 39 per cent.

The aircraft and missile industries consume not merely the lion's share of what the federal government has to spend on industrial research and development, but also use large numbers of skilled people. In 1964 the aircraft and missile industries spent a total of $\$ 5,097$ million on research and development--doubling since 1957-and the federal government contributed $\$ 4,607$ million or 90 per cent of the total. In the same group of industries, a total of 102,600 qualified scientists and engineers were at work in 1964, 85,800 of them on government work. Thus something like one-third of the skilled labour force engaged on research and development in the United States works in airoraft and missiles. The next biggest user of skilled people is the group of industries concerned with making electrical equipment and communications devices, in which 74,800 people were employed.

Like previous instalments, the latest survey has a great deal to say about the cost of employing scientists and engineers on industrial research and development. It has for several years been known that the largest and most successful companies employ greater proportions of scientists and spend more on them, either in salary or in equipment and supporting services. In the past decade, the numbers of scientists and engineers employed in American industry have increased from 21 per 1,000 employees to 29 per 1,000 employees in 1964. The most prolific users are the chemical industry (with 40 scientists and engineers for every 1,000 employees), communications industry (with 64 per 1,000 employees) and aircraft and missiles, where one employee in ten is a scientist or an engineer. The average cost of skilled men has risen comparatively slowly, from $\$ 32,700$ in 1957 to $\$ 38,900$ in 1964 . Although in most groups of industries the annual cost of one skilled man seems to have risen steadilv, in electrical equipment the trend has gone the other way, and the average cost has decreased from $\$ 39,700$ (for this industry alone in 1957 ) to $\$ 35,200$ in 1964. In aircraft and missiles, the average cost of 